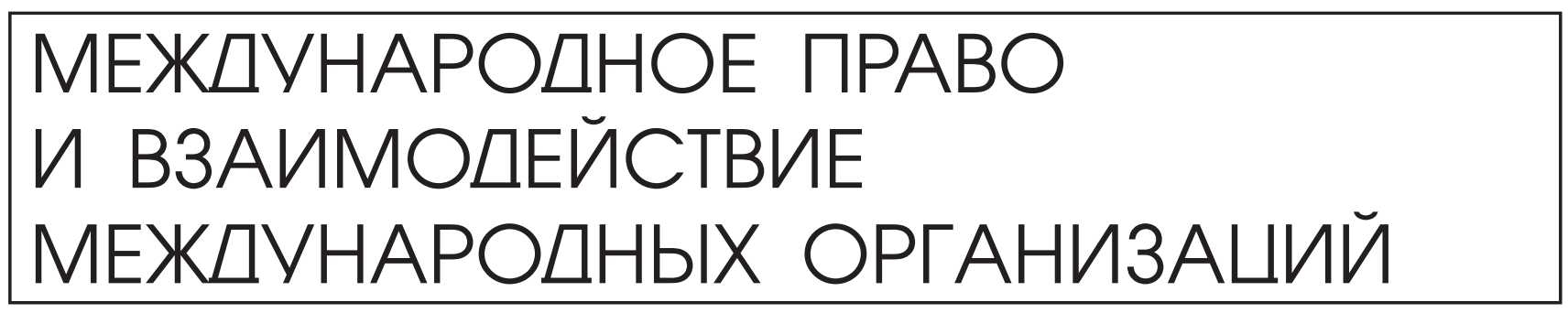

Карпович О.Г.

\title{
МЕЖДУНАРОДНО-ПРАВОВЫЕ ОСНОВЫ МИРОТВОРЧЕСКОЙ ДЕЯТЕЛЬНОСТИ США
}

\begin{abstract}
Аннотация. Аннотация Миротворческая деятельность, осуществлояемая международными организачиями и отдельными странами-мандатариями, является сегодня основным инструментом поддержания мира. В этом отношении наиболее показательна миротворческая деятельность США и их союзников по НАТО, поскольку проводимые ими по всему миру психологические операции по управлению международными конфликтами не только дают богатый фактический материал, но и находят свое отражение в официальных документах, нормативных актах, доктринах и стратегических концепциях, подчеркивая роль и место современных технологий управления конфликтами в международной конкуренщии, в любых формах и проявлениях в современных международных отношениях глобального и регионального противостояния, и их влияние на эволючию современных конфликтов. Также следует отметить, что использование технологий управления международными конфликтами в миротворческих операциях происходит сегодня в условиях формирования нового мирового порядка, возникновения новых центров силь, изменения роли существующих международных институтов и военно-политических блоков, разбалансировки традиционных механизмов обеспечения коллективной безопасности и привнесения в политику радикальных способов достижения целей, ориентированных на одностороннее применение насилия в отношении политических оппонентов, что заметно усложняет течение конфликтов, усложняет организацию контроля и оказание воздействия на них, и, вместе с тем, выдвигает на передний план миротворческой деятельности новые формы и методы внешнего управления процессом конфликтного взаимодействия.
\end{abstract}

Ключевые слова: Международное право, миротворческая деятельность, миротворческие операции, международные конфликты, правовое регулирование, субъекты права, ООН, США, политические технологии, правовое принуждение

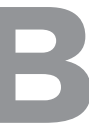

США практика миротворческих операций получила доктринальное закрепление в 1995 году, когда в США было принято наставление Комитета начальников штабов (КНШ) для операций в условиях отсутствия войны (Joint Doctrine for Military Operations Other Than War), в которомвпервые появился раздел «Миротворческие операции». В этом документе констатировалось, что одной из целей операций в условиях отсутствия войны является предотвращение войн путем вмешательства для обеспечения интересов США. Для этого предполагается поддерживать постоянное военное присутствие США за рубежом, чтобы осуществлять на его основе кризисное реагирование. В дальнейшем эти положения были конкретизированы в новом полевом уставе FM 3-0 (2001 год). В британских нормативных военных документах повышенное внимание к миротворческим операциям стало уделяться с 1988 года, когда был принят полевой устав «Миротворческие операции» (Army Field Manual, Volume V. Part 1, Peacekeeping Operations). В нем регламентировалось участие британских военнослужащих в традиционных операциях по поддержанию мира, проводимых под эгидой ООН. В 1993 году появилась новая британская доктрина миротворческих операций, которая нашла свое отражение в полевом уставе (1993 год) «Расширенное поддержание мира» (Army Field Manual-Volume V, Part 2, Wider Peacekeeping). Этот документ был 
разработан специально для действий в рамках сил ОOH UNPROFOR (United Nations Protection Force) в бывшей Югославии; в нем была предпринята попытка приспособить нормы традиционных операций по поддержанию мира к более жестким и неопределенным условиям обстановки, когда продолжается активная фаза конфликта. Поэтому традиционный принцип ООН «неприменение силы» трансформировался в «минимальное применение силы» и «минимально необходимое применение силы», а принцип нейтралитета был заменен на принцип беспристрастности. В 2000 году министерство обороны Великобритании в рамках серии «Совместное ведение войны» издало наставление «Операции по обеспечению мира» (Peace Support Operations. Joint Warfare Publication 3-50). Главной целью документа стала выработка руководящих оперативно-тактических принципов для командиров и штабов в проведении операций по поддержанию мира и принуждения к миру. В будущем планируется дополнить «Операции по обеспечению мира» другим документом, в котором предполагается рассмотреть тактику, приемы и способы действий в таких операциях, в том числе закрепить практику применения новейших технологий управления международными конфликтами (в первую очередь, технологии рефлексивного управления и «управляемого хаоса»).

Миротворческие операции сегодня являются важнейшим полем практического применения современных моделей и технологий управления международными конфликтами. Следует отметить, что основные цели миротворческих операций - стабилизация, урегулирование и разрешение международных конфликтов - являются также основой целеполагания доминирующих мировых моделей управления международными конфликтами. В этом смысле формат миротворческих операций нередко идеально подходит для реализации задач внешнего информационно-психологического управления международными конфликтами:

- цели миротворческих операций, проводимых под эгидой $\mathrm{OOH}$, и операций по управлению конфликтами, проводимых мировыми сверхдержавами, могут совпадать на значительных по длительности интервалах развития конфликтных процессов, что определяет целесообразность объединения усилий и консолидации ресурсов в интересах достижения общих целей;
- формат миротворческих операций в целом весьма выгоден для авторов операций по управлению конфликтами: он придает их операциям легальный статус, благородную окраску, маскируя (на время) их истинные цели, которые могут совсем не сводиться к задачам разрешения международных конфликтов);

- управление международными конфликтами под прикрытием статуса миротворческих операций дает право мировым лидерам на законных основаниях и абсолютно легально вмешиваться в международные конфликты, прикрываясь миротворческой миссией, применять новейшие технологии управления конфликтами, выдавая их за арсенал инструментов управляющего воздействия, разрешенных к применению в миротворческих операциях, и подменять своей деятельностью функции международных институтов.

Миротворческие операции придают технологиям управления международными конфликтами легитимную окраску, легенду прикрытия и официальный статус, то есть предоставляют их носителям законный повод для вмешательства в конфликт. Наличие такого повода по-прежнему считается обязательным во многих случаях и обеспечивает формальную поддержку международных институтов, по крайней мере, в начале операции по управлению конфликтом; кроме того, соблюдение этого правила игры, принятого в международных отношениях, формирует вокруг операции образ благородной миротворческой миссии, что упрощает решение задачи привлечения союзников и обеспечения поддержки миссии с их стороны собственными материальными ресурсами, международным авторитетом и живой силой.

Кроме того, управление конфликтами под флагом миротворческих операций дает возможность мировым лидерам делегировать бремя несения ответственности за конечные результаты эволюции конфликта другим участникам миротворческого процесса, - по сути дела, размывая ее среди широкого круга участников международных отношений, и избегать тем самым прямой и персональной ответственности за неудачи и откровенные провалы в возглавляемой ими миротворческой деятельности.

Со стороны международных институтов, формирующих облик международной миротворческой деятельности и осуществляющих опера- 
тивное управление миротворческими силами в зонах международных конфликтов, проявляется значительный интерес к современным моделям и технологиям управления конфликтами: хотя миротворцев не всегда устраивают конечные цели, в которых мировые сверхдержавы применяют в зонах международных конфликтов технологии внешнего управления, и тот знак равенства, который нередко ставится теми же англосаксами между управлением конфликтами и использованием их в качестве инструмента политического давления на вовлеченные в конфликт стороны, все же большинство авторитетных источников в среде миротворцев не может отрицать их высокую эффективность и способность направлять конфликтные процессы в избранное русло. Причем, сегодня особенно ярко это проявляется в ситуациях, когда традиционные инструменты воздействия на конфликты демонстрируют свою несостоятельность или просто остаются незамеченными со стороны участников конфликтного взаимодействия. Этот интерес только подогревается нарастающим институциональным кризисом ООН, требующим скорейшего поиска новых инструментов воздействия на конфликты и, вероятно, смены самой парадигмы их умиротворения.

В связи с этим сегодня происходит динамичный процесс проникновения технологий управления международными конфликтами в международную миротворческую деятельность, нередко методом прямого заимствования. Это для самих миротворческих операций становится фактором переоценки приоритетов воздействия на конфликты, приводит к размыванию целеполагания (теперь нередко главная цель операции - не разрешение конфликта, а извлечение внешнеполитических выгод и дивидендов для участников миротворческого процесса в результате внешнего управления им) и, в некоторых случаях, полный отказ от устоявшихся ценностей миротворчества в пользу идеологии межцивилизационного противостояния. Под влиянием идеологии управления конфликтами среди миротворцев идет смена приоритетов: в частности, признается, что в некоторых случаях возможность скорейшего разрешения международного конфликта может приноситься в жертву соображениям политической целесообразности, связанной с национальными интересами сверхдержавы, временно подменяющей международные институты в данном миротворческом процессе; вместе с тем, не отрицается, что разрешение конфликтов остается одной из конечных целей их внешнего управления, но только в том случае, если конфликт исчерпал себя как инструмент политического воздействия на других акторов международных отношений, то есть окончательно выдохся (растратив свой конфликтогенный потенциал) и уже никому из участников глобальной политической конкуренции не интересен.

В формате миротворческих операций технологии управления продолжают использоваться акторами международных отношений в рамках своих культурно-цивилизационных моделей, носителями которых они являются: англосаксы действуют строго в рамках англосаксонской модели, европейцы - в рамках романо-германской, китайцы предпочитают традиционную восточноазиатскую модель, а исламский мир - ближневосточную. Иное использование указанных технологий в рамках культурно-цивилизационного подхода представляется невозможным, поскольку, даже находясь в мультикультурной среде, конкретный исполнитель всегда остается идентичным с собственной цивилизационной традицией и будет строить процесс разрешения международного конфликта в соответствие со своей цивилизационной парадигмой, представляющейся ему наилучшей и наиболее совершенной.

Вместе с тем, сам формат миротворческих операций, определяемый строгой классификацией и регламентацией указанной деятельности, существованием официальных методов, процедур ее практической реализации и официальных инструментов воздействия на конфликты, накладывает определенные ограничения на возможности акторов международных отношений по управлению международными конфликтами, становясь для мировых культурно-цивилизационных моделей управления конфликтами рамочным фактором и заставляя вписывать свою деятельность в существующие нормы, регламенты и официальные процедуры миротворческой деятельности.

Это не слишком ограничивает возможности сверхдержав по применению в отношении международных конфликтов собственных культурно-цивилизационных моделей и технологий внешнего управления, хотя и придает этой политической практике определенную специфику. В 
конечном итоге, управлять конфликтами можно и вне рамок миротворческой деятельности; крупнейший актор современных международных отношений - Соединенные Штаты, в тех случаях, когда миротворческие регламенты становятся тормозящим фактором для их движения к конечной цели управления конфликтами, попросту игнорируют некоторые «бюрократические» формальности международного права и международной миротворческой деятельности (нередко демонстративно), либо прекращают себя позиционировать в конфликте как участника официальной миротворческой операции, проводящейся под эгидой ООН. США применяют технологии управления международными конфликтами вне рамок собственно миротворческой деятельности, когда считают себя достаточно сильными или нуждаются в конкретном результате в данной точке политического процесса. Наиболее яркими примерами могут служить недавние конфликты в Южной Осетии, Южном Судане, Ливии, а также цветные революции на пространстве СНГ и их попытках в странах, являющихся убежденными противниками курса США: например, «зеленая революция» в Иране. При этом Вашингтон либо ограничивается сухим комментарием о том, что это нужно в национальных интересах США, либо апеллирует к фактически признанному международным сообществом статусу индивидуального актора миротворческой деятельности, действующего в международном правовом поле на правах международного института.

Однако практика управления конфликтами наглядно демонстрирует, для США технологически и экономически выгодно заручаться формальной поддержкой международных институтов и приобретать для своих операций статус миротворческих везде, где только это возможно: здесь и возможность использования колоссальных ресурсов, накапливаемых мировым сообществом для разрешения конфликтов; и отличная легенда для консолидации союзников, использования их ресурсов и возложения на их плечи основной части рисков, а в некоторых случаях ведение войны их руками; и передаваемые в распоряжение главы миротворческой миссии колоссальные каналы коммуникации, являющиеся средствами доведения до участников конфликтов управляющего психологического воздействия; но в первую очередь, это ресурс мимикрирования, маскировки своих истинных целей от внимания конфликтующих сторон и всего мирового сообщества в целом, обеспечение скрытости подготовки операции и эффекта неожиданности, что для любой операции информационно-психологической войны является главным условием успеха.

Миротворческие операции, в свою очередь, не стоят в застывшем виде и развивают свои концепции и доктрины навстречу парадигмам управления международными конфликтами, двигаясь по пути сближения взглядов и представлений всех мировых течений и сил, претендующих на собственную роль в миротворческой деятельности. При этом происходит сближение и адаптация взглядов традиционных миротворцев, опирающихся на институциональную модель регулирования международных конфликтов, и лидеров глобальной политической конкуренции, рассматривающих международные конфликты как поле столкновения интересов сверхдержав и использующих культурно-цивилизационные модели внешнего управления ими; в практику миротворческой деятельности проникают методы и технологии информационно-психологического воздействия. Институциональная модель регулирования международных конфликтов (главным постулатом которой является утверждение о том, что для решения задачи разрешения международных конфликтов и окончательной стабилизации международных отношений достаточно построить совершенную систему международных институтов, и тогда все проблемы исчезнут сами собой, поскольку они являются прямым следствием несовершенства системы мирового управления), расшатываемая затянувшимся кризисом ОOH, постепенно уступает свои позиции крупнейшим мировым культурно-цивилизационным моделям управления конфликтами, к которым к тому же принадлежат наиболее инициативные миротворцы: США и государства, входящие в состав ЕС и НАТО. Это намечает тенденцию слияния в будущем традиционных форм и методов миротворчества и культурно-цивилизационных моделей и технологий управления международными конфликтами, полностью подменяющего существующий формат миротворческой деятельности. Однако сегодня, пока этот формат еще не прошел полный цикл перепрофилирования под цели и задачи управления конфликтами, он является для моделей и техноло- 
гий информационно-психологического воздействия на международные конфликты принципиальным организующим фактором, определяющем поле, на котором допускается применение технологий управления конфликтами, накладывающим временные рамки и во многих случаях очерчивающим круг ситуаций, в которых использование указанных технологий в миротворческих операциях признается допустимым и оправданным. Это, в конечном итоге, определяет эффективность применения современных культурно-цивилизационных технологий управления международными конфликтами и способность их превращать международный конфликт в инструмент политического воздействия на соперников, формально не выходя при этом за рамки допустимого с точки зрения формата миротворческой деятельности.

Современный формат миротворческой деятельности начал активно формироваться сразу после завершения глобального противостояния двух сверхдержав периода «холодной войны» - США и СССР. До начала 1990-х годов все послевоенные вооруженные конфликты происходили на фоне острейшего противоборства двух противоположных общественно-политических систем и беспрецедентных по своей мощи военнополитических блоков - НАТО и ОВД. Поэтому локальные вооруженные столкновения того времени рассматривались преимущественно как составная часть глобальной борьбы Москвы и Вашингтона за сферы влияния ${ }^{1}$.

С распадом СССР и разрушением биполярной модели устройства мира идеологическое противостояние двух сверхдержав и общественно-политических систем ушло в прошлое, вероятность возникновения мировой войны значительно уменьшилась. Противоборство двух систем «перестало быть той осью, вокруг которой более четырех десятилетий развертывались основные события мировой истории и политики» ${ }^{2}$, что, хотя и открыло широкие возможности для мирного

\footnotetext{
${ }^{1}$ Carver M. War Since 1945. London, 1980. Р. 5; Пирадов A. A. Региональные конфликты, их политическое урегулирование и участие в нем ООН (историко-концептуальное исследование). M., 1990. C. 12-13.

${ }^{2}$ Мунтян М. А. Современные международные отношения: координаты перемен // Некоторые вопросы теории международных отношений. Вып. 1. М.: РАГС, 1995. С. 50.
}

сотрудничества, но и повлекло за собой возникновение новых вызовов и угроз.

В результате распада ялтинско-потсдамской картины мироустройства и прихода на ее место единственного мирового арбитра - Соединенных Штатов - мир погрузился в состояние стратегической нестабильности, сопровождающейся хаотизацией системы международных отношений. Произошла резкая дестабилизация международной обстановки, обострившей скрытые противоречия и отчетливо выявившие линии напряженности внутри отдельных государств, во многих из которых крайне осложнились межнациональные и этноконфессиональные отношения, что спровоцировало многочисленные локальные войны и вооруженные конфликты. Локальные конфликты и просто вооруженные столкновения приобрели способность бесконтрольно разрастаться и за короткий срок поднимать свой статус до международного уровня; малые войны получили возможность эволюционировать до уровня межблокового и межцивилизационного противостояния. С особой остротой эти проблемы проявились в бывших социалистических государствах с федеративным устройством, а также в ряде стран Азии, Африки и Латинской Америки. Так, распад СССР и Югославии привел только в 1989-1992 годах к возникновению более чем 10 этнополитических конфликтов, а на глобальном «Юге» примерно в это же время разразилось более 25 «малых войн» и вооруженных столкновений ${ }^{3}$. Если за первые несколько лет после окончания холодной войны число вооруженных конфликтов в мире сократилось более чем на треть, то уже к середине 1990-х годов оно опять существенно увеличилось ${ }^{4}$. Так, только в 1995 году в 25 различных регионах мира произошло 30 крупных вооруженных столкновений, а в 1994 году по меньшей мере в 5 из 31 вооруженного конфликта государства-участники прибегли к использованию регулярных вооруженных сил 5 .

\footnotetext{
${ }^{3}$ Long War, Short Peace: The Rise and Decline of Ethnopolitical Conflict at the End of the Cold War // People Versus States. US Institute of Peace. May 1999 Revision. P. 10. Table 8.

${ }^{4}$ Аннан Кофи А. Предотвращение войн и бедствий: глобальный вызов растущих масштабов: Годовой доклад о работе ООН за 1999 год. Нью-Йорк, 1999. С. 3.

${ }^{5}$ Ежегодник СИПРИ 1996. Вооружение, разоружение и международная безопасность. М., 1997. С. 31.
} 
Согласно оценкам Комиссии Карнеги по предупреждению смертоносных конфликтов, в 90-е годы $\mathrm{XX}$ столетия только семь самых больших войн и вооруженных противостояний обошлись международному сообществу в 199 млрд долл. США (без учета затрат непосредственно участвовавших в них стран) ${ }^{6}$. Большинство из указанных международных конфликтов новой формации отличалось высокой интенсивностью, сопровождалось массовой миграцией гражданского населения, создававшей угрозу дестабилизации целых регионов и требовавшей организации крупномасштабной международной гуманитарной помощи. Эскалация современных международных конфликтов сегодня идет как по горизонтали (посредством втягивания в них новых стран и регионов), так и по вертикали (происходит увеличение масштабов и интенсивности насилия внутри нестабильных государств).

Миротворчество - метод, впервые предложенный и разработанный $\mathrm{OOH}$, который не поддается простому определению, т. к. имеет множество аспектов и нюансов. Возникнув как международное средство поддержания и установления мира от имени всего мирового сообщества под эгидой $\mathrm{OOH}$, в дальнейшем, после окончания холодной войны, миротворчество прочно вошло в арсенал средств различных региональных и субрегиональных соглашений и организаций․ В качестве примера можно привести миротворческие операции на территории СНГ для урегулирования приднестровско-молдавского, грузино-осетинского, грузино-абхазского конфликтов, а также для прекращения гражданской войны в Таджикистане, инициированные в начале 1990-х годов. Несмотря на первоначальные весьма критические, а порою и резко негативные оценки этих операций западными специалистами, в конце концов им пришлось признать не только статус СНГ как региональной организации безопасности, но и учесть своеобразный опыт проведения этих операций, заслуживающий серьезного анализа ${ }^{8}$. В этот же период времени интересный опыт для становления миротворчества как международного вида деятельности дали миротворческие операции по постконфликтному миростроительству на африканском континенте, также проводившиеся под эгидой $\mathrm{OOH}^{9}$.

Несмотря на то, что в Уставе ООН отсутствует термин «миротворчество», эта международная организация разработала определенную систему приемов, методов и средств, направленных на разрешение споров, прекращение войн и урегулирование вооруженных конфликтов. Эта система включает три основных компонента: 1) мирные средства (по гл. VI Устава), куда входят переговоры, посредничество, установление фактов, добрые услуги, арбитраж и т. п.; 2) полувоенные или квазивоенные средства, представленные, главным образом, традиционными операциями по поддержанию мира; 3) принудительно-силовые средства (по главе VII Устава), как невоенные (экономические, политико-дипломатические, юридические и финансовые санкции), так и военные, с использованием вооруженных сил ООН. В годы холодной войны наибольшее распространение получили операции по поддержанию мира (ОПМ), которые в дальнейшем стали классифицироваться как традиционные ОПМ первого поколения. Помимо соблюдения основополагающих требований для развертывания традиционных операций (согласие всех конфликтующих сторон, заключение сторонами соглашения о перемирии/прекращении огня, применение оружия только в целях самообороны), предполагается также нейтральность и беспристрастность личного состава миротворческих сил (миссий). Потому эти операции весьма ограничены в возможностях и не слишком эффективны для полномасштабного урегулирования кризисов и конфликтов. Однако некоторые из них позволили локализовать конфликт, оказали общее сдерживающее и стабилизующее действие и создали условия для его урегулирования и разрешения мирны-

\footnotetext{
${ }^{6}$ Аннан Кофи А. Предотвращение войн и бедствий: глобальный вызов растущих масштабов: Годовой доклад о работе ООН за 1999 год. Нью-Йорк, 1999.

${ }^{7}$ Шепова Н. Миротворчество как способ предотвращения и урегулирования современных вооруженных конфликтов. // Отечественные записки. - 2005. - №5.
}

\footnotetext{
${ }^{8}$ O'Prey $K$. Keeping the Peace in the Borderlands of Russia. Occasional Paper No 23 // Handbook on UN Peace Operations. By Pamela L. Reed, J. Mathew Vaccaro, William J. Durch. The Henry L. Stimson Center, Wash., D.C., 1995.

${ }^{9}$ Enhancement of African Peacekeeping Capacity. Report of the Secretary-General, 30 November 2004. Doc. A/59/591.
} 
ми средствами ${ }^{10}$. С их помощью порой удавалось «заморозить», «законсервировать» конфликт на длительное время.

С 1989 года под эгидой ООН, наряду с традиционными ОПМ, начали проводиться комплексные операции по поддержанию мира, которые отличаются многофункциональностью и многоаспектностью решаемых задач. Первой подобной операцией стала операция для Намибии (Группа ООН по оказанию помощи в переходный период, инициированная в апреле 1989 года). За ней последовали операции в Западной Сахаре (1991), Камбодже (1991, 1992), операция Сил ООН по охране на территории бывшей Югославии (1992), которая с 1995 года разделилась на три самостоятельные операции, в Сомали (1992, 1993), Руанде (1993), на Гаити (1993, 1996), в Мозамбике (1992), Центрально-Африканской Республике (1998), Восточном Тиморе (1999, 2002), Косово (1999), с привлечением других международных и региональных структур) и ряд других.

С учетом этих новых тенденций в конце 1990-х годов в рамках ООН были пересмотрены подходы к таким фундаментальным принципам традиционного миротворчества, как согласие конфликтующих сторон, нейтралитет и беспристрастность личного состава миротворческих сил и использование ими оружия исключительно в порядке самообороны: если одна из сторон явно нарушает условия мирного соглашения, беспристрастность миротворцев может привести к неэффективности операции в целом (как это имело место в Руанде, Сомали, Югославии). Ничто не нанесло такого ущерба престижу международного миротворчества в 1990-х годах, как нежелание отличать жертву от агрессора. В связи с теми же соображениями трансформировался и принцип применения миротворцами военной силы. Количество вооруженных контингентов различных стран в миротворческих силах $\mathrm{OOH}$, их качественный состав и мощь вооружения стали непрерывно расти.

Между тем, несмотря на существенно возросшие возможности по организации и проведению миротворческой деятельности по всему

${ }^{10}$ Шепова Н. Миротворчество как способ предотвращения и урегулирования современных вооруженных конфликтов. // Отечественные записки. - 2005. - №5. миру, ООН, как показало время, не располагает необходимым для их проведения потенциалом (военным, материально-техническим, финансовым, организационно-техническим). Опыт конфликтов в Персидском заливе, на Балканах, в Афганистане и в других регионах, где ООН была предоставлена возможность урегулировать конфликты, выявил ограниченную способность этой организации заниматься осуществлением задачи установления и поддержания мира. В тех случаях, когда ситуация в зонах международных конфликтов требовала от ООН скорейшего перехода от традиционных методов принуждения к миру к жестким мерам принудительного характера, ООН оказалась не в состоянии сделать это самостоятельно. Примерами такого ступора в миротворческой деятельности стали конфликты в Сомали и Руанде. Хотя, по мнению членов Группы по операциям ООН в пользу мира (авторов т.н. «доклада Брахими»), ООН и не должна этим заниматься: «...Есть много задач, которые не следует ставить перед миротворческими силами $\mathrm{OOH}$, и есть много мест, куда их не следует посылать» ${ }^{11}$.

Это способствует, с одной стороны, развитию тенденции делегирования ООН своих полномочий в области силового миротворчества региональным организациям, отдельным государствам и коалициям государств, готовым взяться за выполнение задач по кризисному реагированию, а. с другой стороны, создало благоприятные условия для выявления двух основных претендентов на роль миротворца, обеспечивающих военную сторону политики управления конфликтами: США и НАТО. Их участие в конфликтах в Сомали (1993) и в Боснии (1995) привело к тому, что миротворческие операции стали считаться одним из специальных направлений деятельности блока НАТО, а также - основной причиной формирования в США жесткого радикального подхода к управлению конфликтами, основанного на активном и упреждающем применении военной силы ${ }^{12}$.

\footnotetext{
${ }^{11}$ Доклад Группы по операциям Организации Объединенных Наций в пользу мира. 17 августа 2000 г. Док. ООН A/55/305-S/2000/809. 55-я сессия ГА ООН. П. 87 предварительной повестки дня «Всестороннее рассмотрение вопроса об операциях по поддержанию мира во всех их аспектах». СБ ООН. 55-й год. П. 1. С. 1.

${ }^{12}$ B.A. Кременюк. Современный международный конфликт: проблемы управления. //Международные процессы, 2008, 24 апр.
} 
Современная миротворческая деятельность, направленная, в первую очередь, на скорейшее урегулирование и разрешение международных конфликтов, требует от актора (государства или международной организации) предельной концентрации ресурсов, наличия политической воли, невозможной в условиях полицентрической системы принятия решений. ООН сегодня в полной мере не отвечает этим требованиям. Напротив, США обладает для этого всеми необходимыми ресурсами. Однако существует группа государств, включающая влиятельных участников международных отношений (Россия, Китай, Франция, Германия), которая не желает доверять Соединенным Штатам функцию контроля над конфликтами, считая, что это увеличит международные активы США и создаст угрозу их собственному суверенитету ${ }^{13}$. Это снижает эффективность применения англосаксонской модели управления международными конфликтами и ее способность переводить существующие конфликты в мирную фазу.

Современные миротворческие операции во всех их видах и формах, от превентивной дипломатии до разумного применения силы, сегодня являются действенным способом предотвращения, контроля, стабилизации, урегулирования и разрешения международных конфликтов. По словам бывшего Генерального секретаря ООН Кофи Аннана, миротворческие операции «при соответствующих условиях... могут представлять собой гибкий и уникально адаптированный механизм противодействия конфликтам» ${ }^{14}$. Их организационные формы реализации включают в себя пять составляющих: превентивную дипломатию, операции по поддержанию мира, операции по принуждению к миру, операции по содействию миру или собственно миротворческие операции, и операции по постконфликтному миростроительству. Этот набор организационных форм реализации миротворческой деятельности и сосотвествующие каждой форме наборы политических методов и

\footnotetext{
${ }^{13}$ B.А. Кременюк. Современный международный конфликт: проблемы управления. //Международные процессы, 2008, 24 апр.

${ }^{14}$ Аннан Кофи А. Причины конфликтов и содействие обеспечению прочного мира и устойчивого развития в Африке. Доклад ГС ООН, 13 апреля 1998 года. Док. ООН. А/52/871 - S/1998/318. C. 11.
}

процедур воздействия на конфликты определяют формат, в котором сегодня в миротворческих операциях применяются современные технологии управления международными конфликтами.

В этой системе организационных форм и направлений миротворческой деятельности под превентивной дипломатией (англ. preventive diplomacy) понимаются меры, направленные на предупреждение разногласий между сторонами, недопущение перерастания споров в международные конфликты и ограничение масштабов и темпов разрастания уже существующих международных конфликтов, предотвращение скатывания в неуправляемую фазу и в вооруженный хаос. В рамках превентивной дипломатии предполагается широкое использование различных мер по укреплению доверия, создание миссий по сбору фактов и систем раннего предупреждения об угрозах миру, использование демилитаризованных зон как превентивной меры, возможностей института медиаторства и международного посредничества и т.д. В качестве предупредительной меры в рамках операций по превентивной дипломатии допускается демонстрация силы в зонах конфликтов, включающая развертывание миротворческих сил ООН или миротворческих контингентов уполномоченных стран в качестве меры предупреждения конфликтующим сторонам, предполагающее значительный психологический эффект.

Превентивная дипломатия исключительно удобна для отработки стадии первоначальной подготовки операций информационно-психологической войны и операций по управлению международными конфликтами: она позволяет силам специальных операций начать развертывание сил и средств по управлению конфликтами и приступить к массированной психологической обработке массового и индивидуального сознания конфликтующих сторон, маскируя свою деятельность под превентивные дипломатические меры. Эта же легенда позволяет силам специальных операций, не вмешиваясь напрямую в конфликт и тем самым не рискуя раскрыть свои планы, начать в штатном режиме сегментацию информационного пространства, разделение его на целевые аудитории, выделение в них лидеров мнений, способных направлять политическую активность общества и власти в нужное русло, а также приступить к подготовке каналов коммуникации и доставки 
управляющего воздействия до сознания целевых аудиторий, установке первоначальных контактов с лидерами противоборствующих сторон и т.д. С точки зрения успешности любой психологической операции по управлению международным конфликтом наличие такого легитимного прикрытия как превентивная дипломатия для деятельности международного актора по подготовке к применению в отношении участников конфликта технологий психологического воздействия является исключительно важным фактором: классическая схема операции по управлению международным конфликтам включает в себя длительную скрытую стадию, в которой воздействие на конфликт и его участников осуществляется в полной мере, но при этом остается самими участниками конфликта нераспознанным; в случае раскрытия факта проведения специальной операции на ее ранних стадиях это может поставить под угрозу ее конечную цель и подорвать позиции инициатора такой операции в самом конфликте.

Сам характер и статус превентивной дипломатии, также как и ее формат, предоставляет ведущим акторам международных отношений дополнительные возможности воздействия на конфликты и вмешательства во внутренние дела их участников, прикрываясь при этом политической необходимостью и целесообразностью: цель миссии превентивной дипломатии - предупредить угрозу и локализовать ее на самой ранней стадии, когда она еще не созрела и, возможно даже, еще полностью не проявилась. Превентивная дипломатия во всех случаях должна носить упреждающий характер, поэтому в ней де факто допускается использование форм и методов воздействия на конфликты и их участников, не всегда вписывающиеся в требования нормативных документов $\mathrm{OOH}$, и некоторые отклонения от официально принятых в миротворчестве политических процедур, а также несколько вольная их интерпретация в каждой конкретной ситуации, - если этого требует необходимость принятия стратегического решения, а времени на оценку взвешенности самого решения, точного соответствия его существующей политической ситуации и необходимых для организации этого процесса ресурсов в наличии нет. Необходимость срочно принимать упреждающие меры часто служит оправданием принимаемых в данной ситуации «сырых» и попросту ошибоч- ных решений; не говоря уже о том, что часто неверно распознается и формулируется сама угроза, а также ее возможные источники. В силу этих причин формат превентивной дипломатии позволяет сверхдержавам, рассматривающим международные конфликтов как поле столкновения интересов и инструменты оказания давления на политических оппонентов, сразу перейти к использованию в отношении конфликтов своих национально-государственных и культурно-цивилизационных технологий внешнего управления, соблюдая при этом по отношению к собственно миротворческой миссии необходимые минимально возможные формальности.

В отличие от операций превентивной дипломатии, операции по поддержанию мира (англ. peacekeeping operations) предполагают использование в миротворческой деятельности института военных наблюдателей, многонациональных вооруженных сил, миротворческих сил государствчленов ООН (по решению Совета Безопасности, в отдельных случаях - Генеральной Ассамблеи), или государств - членов региональных соглашений (по решению соответствующего органа). Цель указанных операций - обеспечение соблюдения условий прекращения огня и разъединения сил уже после заключения соглашения о перемирии. В документах ООН они обычно определяются следующим образом: «Операция по поддержанию мира - это действия с участием военнослужащих, не имеющих права прибегать к использованию принудительных мер, предпринимаемые Объединенными Нациями с целью поддержания или восстановления международного мира и безопасности в районе конфликта» ${ }^{15}$. Для проведения ОПМ требуются добровольное согласие и сотрудничество всех заинтересованных сторон. Задействованный в операции военный персонал выполняет поставленные задачи, не прибегая к силе оружия (кроме как в целях самообороны; в случае попыток со стороны отдельных лиц/групп помешать миротворцам осуществлять задачи, оговоренные в мандате операции; для защиты гражданского персонала миротворческой миссии или других международных, региональных, общественных и т. П. организаций, действующих в

\footnotetext{
${ }^{15}$ The Blue Helmets. A Review of United Nations Peace-keeping. $2^{\text {nd }}$ ed. UN DPI. N.Y., 1990.
} 
районе конфликта), чем операции по поддержанию мира отличаются от принуждения к миру, предусмотренного в ст. 42 [главы VII] Устава ООН» ${ }^{16}$.

Вместе с тем, как указывает Богатуров А.Д., серия серьезных провалов 1993-1994 гг. в области регулирования локально-региональных конфликтов не только в странах «третьего мира» (крах многонациональной операции в Сомали, кровопролитные межплеменные столкновения в Бурунди и Заире, обострение ситуации в Афганистане и Анголе и др.), но и в центре Европы (на территории бывшей Югославии), позволили выдвинуть тезис о том, что «традиционное миротворчество», доминировавшее в таких международных организациях, как $\mathrm{OOH}$, больше не срабатывает ${ }^{17}$. Это стало причиной того, что США, их европейские союзники по НАТО в миротворческой деятельности стали делать ставку на одностороннее, преимущественно силовое, разрешение конфликтных ситуаций при игнорировании $\mathrm{OOH}$ как универсальной организации. Вместе с тем, для традиционных операций по поддержанию мира эти неудачи стали важным сигналом и стимулом к развитию, универсализации концепций и их структурному и функциональному усложнению.

Начиная со второй половины 1990-х гг. происходит непрерывное усложнение традиционной модели (и сопутствующих ей концепций) операций по поддержанию мира, расширение ее функций и компетенции, а также включение в арсенал операций новых методов и технологий воздействия. Традиционные операции по поддержанию мира всегда осуществляются в рамках «главы VI с половиной» Устава $\mathrm{OOH}$ (по определению Генерального секретаря $\mathrm{OOH}$ Д. Хаммаршельда $\left.{ }^{18}\right)$, т.к. не предполагают применения принудительно-силовых мер. Более сложные и масштабные операции по поддержанию мира, если того требует обстановка в зоне конфликта, учреждаются на основании главы VII, что находит отражение в их мандате. Они допу-

\footnotetext{
${ }^{16}$ The Blue Helmets. A Review of United Nations Peace-keeping. $2^{\text {nd }}$ ed. UN DPI. N.Y., 1990. P. 4-5.

${ }^{17}$ См.: Богатуров А.Д. /Ред./, Системная история международных отношений, 1918-2003, в 4 т. - М. 2003; Морозов Г.И., $\mathrm{OOH}$ на рубеже XXI века (кризис миротворчества ООН). // Доклады Института Европы, 1999, №55.

18 Даг Хаммаршельд - Генеральный секретарь ООН с апреля 1953 года по сентябрь 1961 г.
}

скают ограниченное применение силы не только для самообороны, но и для прямого воздействия на участников международного конфликта.

Формат операций по поддержанию мира позволяет осуществлять управление международными конфликтами, имея в среде его участников точки входа для внешнего управляющего психологического воздействия: это - гражданское население и общественные организации, которые миротворческие силы обязаны защищать, даже силой оружия. Этот канал проникновения в конфликтную среду дает возможность организовать работу многочисленных общественных (неправительственных) организаций с тем, чтобы сформировать на их основе молодежное протестное движение, полезное для реализации технологий цветных революций (если задачи управления международным конфликтом потребуют смену политического режима) или создать канал для распространения идеологического воздействия по схемам сетевой коммуникации. При этом организаторы операции по управлению международным конфликтом могут дозировать свое присутствие в конфликте, оказывая на него управляющее воздействие отдельными порциями или залповыми выбросами, поочередно используя для вмешательства в ход конфликта различные точки входа и внешние поводы.

В традиционных операциях по поддержанию мира главная цель состоит в защите мирного населения, то есть речь в основном идет не столько об урегулировании или разрешении конфликта, сколько о временном его «замораживании», предпочтительно мирными средствами. В этом случае технологии информационно-психологического воздействия на конфликт и его участников выдвигаются на передний план миротворческой деятельности самой логикой развития событий; при этом деятельность по «поддержанию мира» по отношению к течению международного конфликта напрямую заменяется категориями его внешнего управления. Формат миротворческих операций по поддержанию мира отлично подходит и для осуществления «цветных революций», включая их итерационные цепочки с внедренным в классическую технологию «цветных революций» механизмом обратной связи, продемонстрированные мировому сообществу в ходе «финиковых революций» «арабской весны» на Ближнем Востоке и в Северной Африке. 
Принуждение к миру (англ. peace enforcement) - это форма вооруженного вмешательства, принятие принудительно-силовых и иных мер по отношению к государству-агрессору или стороне конфликта, не желающей выполнять требования международных или региональных организаций безопасности и угрожающей международному (региональному) миру.

Операции по принуждению к миру (англ. реасе enforcement operations) предполагают использование в миротворческой деятельности вооруженных сил $\mathrm{OOH}$, региональных организаций безопасности или коалиций стран, уполномоченных $\mathrm{OOH}$ на ведение такого рода деятельности. Принуждение к миру не требует согласия враждующих сторон на такой формат вмешательства международного сообщества в конфликт. В ходе операций по принуждению к миру вооруженные контингенты миротворцев используются не только в целях самообороны, но и по прямому назначению: для уничтожения военных объектов и инфраструктур, вооруженных группировок (незаконных военизированных формирований, бандформирований и т. п.), препятствующих локализации конфликта, его урегулированию и разрешению. Подобные операции проводятся в рамках главы VII Устава ООН, предусматривающей принудительные действия (меры), только с санкции Совета Безопасности ООН и под его контролем.

Возможность широкого применения вооруженной силы позволяет управлять международными конфликтами, сочетая боевые операции и операции психологической войны. Одним из примеров такого сочетания является война в Ираке 2003-04 гг., в ходе которой боевые действия стали сервисом по отношению к операциям психологической войны, планировались и проводились руководством США в формате (режиме) телевизионных новостей, а сам вооруженный конфликт, по сути, стал конвейером для производства пиар-новостей, использовавшихся затем для осуществления внешнего информационного воздействия и манипулирования сознанием мирового сообщества. Этот подход характерен для почерка США и англосаксов вообще, но это совсем не означает, что форматом принуждения к миру не пользуются в своих операциях по управлению международными конфликтами западные европейцы - представители рома- но-германского культурно-цивилизационного подхода. Для них организуемый англосаксами конвейер по производству новостей становится полем для широкой политической интерпретации событий (доходящих до массового зрителя в заметно купированном и рецензированном виде), придании им новых смыслов, конструировании собственных образов конфликта и продвижении этих образов в сознании собственного населения и мировой общественности в целом с помощью технологий политического маркетинга. Для европейцев образ конфликта является продуктом потребления, а сама политика - искусством интерпретации фактически произошедших событий, в ходе которой стирается грань между реальностью и привнесенными в эту реальность дизайнерскими элементами.

Не менее эффективно в формате принуждения к миру работают и новейшие технологии управления международными конфликтами, такие как технологии управляемого хаоса и рефлексивного управления. Так, военный ресурс позволяет сломить сопротивление тех структур в традиционных обществах (в первую очередь на Востоке, где эти технологии преимущественно применяются), которые не поддаются попыткам разрушения традиционного уклада (социальной «атомизации» общества) и девальвации традиционных ценностей, а также защищают своих членов от разрушительного для их сознания и культурно-цивилизационной идентичности внешнего психологического воздействия. С точки же зрения теории рефлексивного управления, военное воздействие или угроза его применения в отношении международного конфликта дает самый мощный рефлексивный отклик со стороны участников конфликта, в рамках лежащей в основе рефлексивного управления схеме «стимул-реакция».

Операции по содействию миру, или собственно миротворческие операции, (англ. peacemaking) это специальная форма и направление миротворческой деятельности, преследующая цели свести в международном конфликте все противоборствующие стороны за столом переговоров с целью выработки общей формулы согласия и заключения политических компромиссов, что в существующей практике урегулирования международных конфликтов достигается главным образом с помощью переговоров, посредничества, примирения, 
оказания взаимных услуг, арбитража и других мирных (невоенных) средств, предусмотренных в главе VI Устава ООН. Эта миссия осуществляются, как правило, политиками, дипломатами, видными общественными и государственными деятелями, представителями Генерального секретаря ООН. Нередко в качестве инициатора такой миссии выступает и индивидуальный актор миротворческой деятельности - государство, уполномоченное $\mathrm{OOH}$ (например, США), или возглавляемый им военнополитический блок (НАТО).

Для ведущих мировых держав, стремящихся под видом миротворчества превратить международные конфликты в объекты внешнего управления, возможности медиаторства, осуществляемого под эгидой ООН, открывают существенные возможности для внедрения в конфликт. Не меньшее значение для внедрения в среду участников конфликта и различных политических сил, отстаивающих в конфликте свои интересы, имеет и сам статус медиатора, международного посредника, пользующийся уважением среди конфликтующих сторон.

Вместе с тем, эффективность применения культурно-цивилизационных моделей и технологий управления международными конфликтами в операциях по содействию миру затруднена существованием ряда процедурных ограничений, накладываемых форматом этого направления миротворческой деятельности на свободу применения сил и средств внешнего управляющего воздействия. Источником таких ограничений служит переговорное пространство (BATNA), содержащее в себе все допустимые в данном международном конфликте политические решения, принимаемые в интересах его мирного урегулирования либо разрешения, и имеющее при любом формате медиаторства четкие границы. Эти границы носят рамочный характер для применяемых в том же миротворческом процессе (либо под его прикрытием) моделей и технологий управления международными конфликтами: вместе с ограниченным набором политических решений, допустимых в данном международном конфликте, BATNA накладывает ограничения и на применяемые в конфликте методы и технологии внешнего управляющего воздействия, сводя их к определенному набору допустимых и разрешенных политических процедур. Это в организационном плане в определенной мере ско- вывает мобильность сил специальных операций по управлению международными конфликтами и ограничивает им оперативный простор. С другой стороны, для моделей и технологий управления международными конфликтами, основанными на психологическом воздействии, эти рамки во многом имеют формальное значение: применение технологий информационно-психологического воздействия на сознание конфликтующих сторон даже в наиболее опасных и агрессивных формах - в операциях информационной войны - ничем не ограничивается, даже нормами международного права, в котором эта сфера социально-политических отношений как объект правового регулирования отсутствует полностью.

Не меньшим значением для управления международными конфликтами и закрепления его результатов в сознании бывших участников имеют операции по постконфликтному миростроительству (англ. post-conflict peace-building) - это направление миротворческой деятельности, предполагающее управление социально-политической жизнью в зоне конфликта, перешедшего в стадию угасания или «заморозки», в интересах выявления и искоренения истинных причин конфликта и восстановления нормальных условий для жизни. Миростроительство включает в себя (но не ограничивается только этим) разоружение и реинтеграцию бывших комбатантов в гражданское общество, восстановление разрушенных в ходе конфликта экономических, общественно-политических, коммуникационных и иных структур, возвращение беженцев и перемещенных лиц, укрепление правопорядка (например, через подготовку кадров и реформирование структуры местной полиции, проведение реформ судебной и пенитенциарной систем), обеспечение соблюдения прав человека, оказание технической помощи в демократическом развитии, а также поощрение мирных методов урегулирования конфликтов, ликвидации причин и условий их возобновления.

В операциях по управлению международными конфликтами формат постконфликтного миростроительства используется в основном в следующих целях:

- в целях закрепления результатов воздействия на сознание участников конфликта информационно-психологических технологий, применяемых в моделях управления конфликтами; 
- в целях внедрения в сознание населения, представителей властных структур и этнической элиты новой системы ценностей (в случае англосаксов - «демократических свобод»), построенной на этой системе идеологии, миропонимании и мироощущении, формирование новой политической идентичности, позволяющей сделать этот электорат убежденными сторонниками политического курса другого государства, в интересах которого и осуществлялось управление конфликтом;

- в целях закрепления внедренных в сознание и социально-политическую структуру общества механизмов осуществления внешнего рефлексивного управления его социальной и политической активностью;

- в целях внедрения в подсознание общества новых исторических архетипов, позволяющих в случае необходимости инициировать этот временно погашенный конфликт в любой момент с помощью внешнего управляющего импульса, и снова превратить его в точку столкновения интересов ведущих мировых игроков.

Таким образом, в постконфликтной стадии представители ведущих мировых держав нередко используют формат миростроительства для того, чтобы закрепить в регионе собственные интересы, в сознании населения - результаты психологического воздействия, в социально-политических структурах - внедренные в их деятельность механизмы внешнего контроля и управления, а также подготовить почву для возможной активации этого конфликта в будущем.

Наличие пяти различных форматов официальной миротворческой деятельности, подразумевающие существование пяти различных правовых режимов, дает возможность индивидуальным акторам, возглавляющим миротворческие операции в регионах, гибко комбинировать и сочетать эти форматы в интересах достижения собственных целей управления международными конфликтами, переходить из одного формата в другой в зависимости от изменения политической обстановки и использовать в своих интересах многочисленные квазиправовые расширенные толкования компетенции миротворческих сил в каждом из указанных форматов реализации миротворческой деятельности. И наиболее изобретательно этими возможностями пользуется в своих операциях по управлению международными конфликтами Соединенные Штаты Америки.

\section{Библиография:}

1. Боженко В.А. Роль ООН в деле предотвращения конфликтов и поддержание международной безопасности // ООН и международный правопорядок в глобализирующемся мире:Материалы международной научно-практической конференции, Москва, 24 октября 2007 г - М. Изд-во РУДН, 2008.

2. Замышляев Д.В. Национальные интересы и обеспечение национальной безопасности государства в рамках концепций международных отношений // Международное публичное и частное право. М. Юрист, 2010

3. Кортунов А.В. «Россия и реформы ООН.», М., 2009

4. Крылов С.Б. История создания Организации Объединенных наций: Разработка текста Устава ООН. М., ИМО. 2008.

5. Carver M. War Since 1945. London, 1980. Р. 5; Пирадов А. А. Региональные конфликты, их политическое урегулирование и участие в нем ООН (историко-концептуальное исследование). М., 1990. С. 12-13.

6. Мунтян М. А. Современные международные отношения: координаты перемен // Некоторые вопросы теории международных отношений. Вып. 1. М.: РАГС, 1995. С. 50.

7. Long War, Short Peace: The Rise and Decline of Ethnopolitical Conflict at the End of the Cold War // People Versus States. US Institute of Peace. May 1999 Revision. P. 10. Table 8.

8. Аннан Кофи А. Предотвращение войн и бедствий: глобальный вызов растущих масштабов: Годовой доклад о работе ООН за 1999 год. Нью-Йорк, 1999. С. 3.

9. Аннан Кофи А. Причины конфликтов и содействие обеспечению прочного мира и устойчивого развития в Африке. Доклад ГС ООН, 13 апреля 1998 года. Док. ООН. А/52/871 — S/1998/318. 
10. Шепова Н. Миротворчество как способ предотвращения и урегулирования современных вооруженных конфликтов. //Отечественные записки. - 2005. - №5.

11. O'Prey K. Keeping the Peace in the Borderlands of Russia. Occasional Paper No 23 // Handbook on UN Peace Operations. By Pamela L. Reed, J. Mathew Vaccaro, William J. Durch. The Henry L. Stimson Center, Wash., D.C., 1995.

12. Enhancement of African Peacekeeping Capacity. Report of the Secretary-General, 30 November 2004. Doc. A/59/591.

13. Доклад Группы по операциям Организации Объединенных Наций в пользу мира. 17 августа 2000 г. Док. ООН А/55/305-S/2000/809. 55-я сессия ГА ООН. П. 87 предварительной повестки дня «Всестороннее рассмотрение вопроса об операциях по поддержанию мира во всех их аспектах». СБ ООН. 55-й год. П. 1. С. 1.

14. The Blue Helmets. A Review of United Nations Peace-keeping. 2nd ed. UN DPI. N.Y., 1990.

15. Богатуров А.Д. /Ред./, Системная история международных отношений, 1918-2003, в 4 т. - М. 2003/

\section{References (transliteration):}

1. Bozhenko V.A. Rol' OON v dele predotvrashhenija konfliktov i podderzhanie mezhdunarodnoj bezopasnosti // OON i mezhdunarodnyj pravoporjadok v globalizirujushhemsja mire:Materialy mezhdunarodnoj nauchno-prakticheskoj konferencii, Moskva, 24 oktjabrja 2007 g - M. Izd-vo RUDN, 2008.

2. Zamyshljaev D.V. Nacional'nye interesy i obespechenie nacional'noj bezopasnosti gosudarstva $\mathrm{v}$ ramkah koncepcij mezhdunarodnyh otnoshenij // Mezhdunarodnoe publichnoe i chastnoe pravo. - M. Jurist, 2010

3. Kortunov A.V. «Rossija i reformy OON.», M., 2009

4. Krylov S.B. Istorija sozdanija Organizacii Ob\#edinennyh nacij: Razrabotka teksta Ustava OON. M., IMO. 2008.

5. Carver M. War Since 1945. London, 1980. P. 5; Piradov A. A. Regional'nye konflikty, ih politicheskoe uregulirovanie i uchastie v nem OON (istoriko-konceptual'noe issledovanie). M., 1990. S. 12-13.

6. Muntjan M. A. Sovremennye mezhdunarodnye otnoshenija: koordinaty peremen // Nekotorye voprosy teorii mezhdunarodnyh otnoshenij. Vyp. 1. M.: RAGS, 1995. S. 50.

7. Annan Kofi A. Predotvrashhenie vojn i bedstvij: global'nyj vyzov rastushhih masshtabov: Godovoj doklad o rabote OON za 1999 god. N'ju-Jork, 1999. S. 3.

8. Annan Kofi A. Prichiny konfliktov i sodejstvie obespecheniju prochnogo mira i ustojchivogo razvitija $\mathrm{v}$ Afrike. Doklad GS OON, 13 aprelja 1998 goda. Dok. OON. A/52/871 — S/1998/318.

9. Shepova N. Mirotvorchestvo kak sposob predotvrashhenija i uregulirovanija sovremennyh vooruzhennyh konfliktov. //Otechestvennye zapiski. - 2005. - №5.

10. O'Prey K. Keeping the Peace in the Borderlands of Russia. Occasional Paper No 23 // Handbook on UN Peace Operations. By Pamela L. Reed, J. Mathew Vaccaro, William J. Durch. The Henry L. Stimson Center, Wash., D.C., 1995.

11. Bogaturov A.D. /Red./, Sistemnaja istorija mezhdunarodnyh otnoshenij, 1918-2003, v 4 t. - M. 2003/ 